\title{
Immigrant Language Proficiency, Earnings, and Language Policies ${ }^{1}$
}

\author{
Monica Boyd \\ Department of Sociology \\ University of Toronto \\ monica.boyd@utoronto.ca
}

\author{
Xingshan Cao \\ Arthritis Community Research and Evaluation Unit \\ Western Hospital,Toronto \\ xs.cao@utoronto.ca
}

\begin{abstract}
This paper addresses two questions: 1) what are the impacts of language proficiency on the earnings of Canadian adult immigrants; 2) what are the current policy responses. Using a five-level scale of English/French language use, our analysis of Public Use Microdata File for the 2001 census confirms the positive association between proficiency in Canada's charter language(s) and immigrant earnings. Compared to permanent residents who are highly proficient in English and/or French, those with lower levels of proficiency have lower weekly earnings. Quantile regressions reveal that the relative advantage of English/French language proficiency is higher for those in the top quarter of the earnings distribution; conversely, greater penalties exist for immigrants with low levels of language proficiency at the upper end of the earnings distribution. The likely impacts of federal policies on increasing English/French language proficiency of immigrant workers are discussed, focusing on two federal government initiatives for language training and two recent immigration policy changes.
\end{abstract}

Keywords: Language proficiency, immigrant labour force, migrant policies, immigrant earnings, government programs

\section{Résumé}

Cet article adresse deux questions : 1) quels sont les effets de la maîtrise de la langue sur les gains des immigrants canadiens adultes, et 2) quelles sont les politiques correctives actuelles. En nous servant d'une échelle à cinq niveaux d'usage des langues française et anglaise, notre analyse des microdonnées à grande diffusion du recensement de 2001 confirme la relation

1. Acknowledgments: This paper was funded as part of the Canada Research Chair, Tier I awarded to Monica Boyd. The authors thank Melissa Moyser for her research assistance with the literature on language as human capital. 
positive entre la maîtrise d'une ou des deux langues officielles du Canada et les gains des immigrants. Comparés aux résidents permanents qui ont une excellente maîtrise du français et/ou de l'anglais, les immigrants qui ont des bons niveaux de maîtrise de ces langues gagnent des salaires hebdomadaires plus réduits. Les régressions par quantiles révèlent que la maîtrise $d u$ français et/ou de l'anglais apporte un plus grand avantage pour ceux dans le quart supérieur de la répartition des gains; inversement, les immigrants de la tranche la plus élevée de la répartition des gains avec une faible maîtrise d'une des langues officielles sont plus fortement pénalisés. Les effets possibles des politiques fédérales sur l'augmentation de la maîtrise $d u$ français et de l'anglais pour les travailleurs immigrants sont discutés, et une emphase est placée sur deux interventions de cours de langues du gouvernement fédéral ainsi que deux changements récents dans la politique d'immigration.

Mots clés : maîtrise de langue, gains des immigrants, politique d'immigration

\section{Introduction}

International migration, here defined as the movement of people across international borders for purposes of permanent settlement, has long contributed to Canada's population growth, to its economic and political development, and to its demographic and social diversity. The importance of migration is evident not only in historical recruitment efforts, but also in Canadian immigration policies of the 20th and 21st centuries (Kelley and Trebilcock, 1998; Knowles, 2007). During the latter half of the 20th century, immigration policies - a set of principles on who shall be admitted, accompanied by a course of action regulating such flows - were accompanied by migrant policies, notably frameworks and actions supporting the integration of new migrants. Because of the specificity of targeting newcomers, such policies seldom are included in discussions of social policy. Yet state-mandated migrant policies can ameliorate inequalities between migrants and the larger population; accordingly, migrant policies - while not applicable to the entire host country population - are a subset of social policies to increase human welfare.

In Canada and elsewhere, language training is a key component of migrant policy. Improvements in the linguistic proficiency of immigrants represent investments in the social and economic spheres. Knowing the language(s) of the host society enhances the capacity to obtain information about schools, health care, social programs, housing, employment opportunities, unemployment benefits, and civic and legal rights in the new society. By improving the stock of knowledge and enlarging networks and opportunities, host country language proficiency improves social capital and increases the likelihood of successful social integration for immigrants. Language also is a form of economic capital; knowing the host country 
language(s) increases the productivity of immigrant workers and thus, under the assumptions of neoclassical economics, their wages. Conversely, lack of familiarity with the host country language(s) is associated with unemployment, underemployment, and low wage jobs (Boyd, 1999); in turn, the latter consequences have the potential to retard social integration.

This paper addresses two questions that emerge from the dual themes of language as a human resource, particularly in the labour market, and as a domain of social policy. First, what are the consequences of language proficiencies for Canadian adult immigrants, particularly with respect to labour market earnings? We go beyond standard analyses by showing that the costs of not knowing English or French vary along the income distribution. Gaps in earnings by levels of language proficiency are greatest for immigrants who are in jobs characterized by high earnings. Second, are current policy responses likely to improve linguistic capabilities in the future, particularly for immigrant workers with poor language proficiency? The answers are in both migrant and immigration policy. Regarding settlement, government funding for language training of immigrants has been present for several decades in Canada. However, our analysis of publicly available documents suggests that these programs are not likely to substantially reduce the population of immigrants in the labour force with poor English/French language proficiencies. Canada's immigration policy - those goals and programs that determine who shall be legally admitted for purposes of permanent residence - has undergone recent change that could reduce future numbers of highly skilled immigrants in need of language training. Currently, the impact of the most recent change, the establishment of the Canadian Experience Class, appears to be minimal.

\section{Why Language Proficiency Matters: Demographic and Economic Contexts}

Whether they came as Clifton Sifton "stalwart peasant[s]" in the early 1900s (Kelly and Trebilcock, 1998:120) or as industrial workers, the nonBritish Isles and non-French origins of many immigrants to Canada suggest that a substantial number arriving prior to the mid-1900s were not fluent in English and/or French (Boyd and Vickers, 2000). Although historical estimates of language knowledge for entering immigrants are scarce during the first seven decades of the 1900s, a research report associated with the 1974 Green Paper finds that the percentages of arrivals who did not speak English and/or French ranged from 30-39\% in the years between 1968 and 1972 (Manpower and Immigration, 1974:Table 6.3). As shown in Figure 1, such 


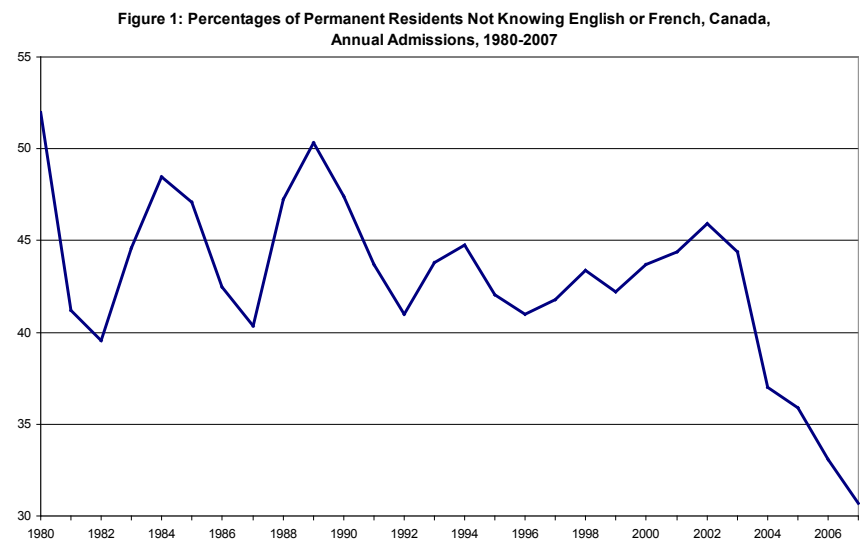

low levels were not to be attained until nearly thirty-five years later. Only in 2004 did levels drop below $39 \%$, declining to $31 \%$ in 2007 , the last year for which data are publicly available.

During 2004-2007, there were no noteworthy changes in entry class composition, which in Canada includes persons admitted on the principles of family reunification, humanitarian concerns, and economic contributions. The drop in the percentages not knowing English or French likely reflects a more aggressive management of in-flows based on English/French language competency. The Immigration and Refugee Protection Act (IRPA), which came into force June 28, 2002, increased the maximum contribution of high language proficiency for principal applicants in the skilled workers class, from $25 \%$ of the minimum score of 60 required in earlier regulations to $36 \%$ of a minimum 67 points. In addition, the percentages of permanent residents admitted annually who knew English and/or French increased from 2004 onwards for those in the family and humanitarian (refugee) classes (Citizenship and Immigration Canada, no date).

The importance of language skills for integration purposes was highlighted throughout the 1990s in a series of research reports that followed a sample of new immigrants over a four-year period. The Longitudinal Survey of Immigrants (LSIC) interviewed approximately 12,000 permanent residents about six months after their arrival between April 2001 and May 2002. Within the first 6 months of arrival, over $70 \%$ of permanent residents reported problems finding jobs; the third most prominent reason given was language difficulties, following lack of Canadian experience and transfer of foreign education (Statistics Canada, 2005). Four years after their arrival in Canada, respondents were asked what had been the greatest difficulties they had encountered. The two main difficulties were finding an adequate job 
(46\% of immigrants) and learning English or French (26\%). Further, knowledge of the two official languages was an asset in finding paid employment. LSIC data for each of the survey's three waves showed that the employment rate of immigrants aged 25-44 increased with higher levels of self-reported proficiency in spoken English. More specifically, immigrants whose selfreported level of spoken English was good or very good were more likely to have a high-skill job, a job in the intended field, a job similar to the one held before immigrating, or a job related to training or education. They also had higher wages, compared to immigrants whose spoken English level was not as good. This was true six months, two years, and four years after immigrants' arrival in Canada (Grondin, 2007; Statistics Canada, 2007).

Why is host country language proficiency an important determinant of earnings? The answer to this question is almost self-evident: according to economists, proficiency in the host country language(s) is a form of human capital, representing a skill that enhances the productivity and thus the wages of workers (e.g. Bellante and Kogut, 1998; Bleakley and Chin, 2004; Carnevale, Fry, and Lowell, 2001; Chiswick and Miller, 2002; Dustmann and Van Soest, 2002; Park, 1999; Shields and Price, 2002). Language proficiency increases earnings in three ways. First, because it facilitates oral and written communication with supervisors, subordinates, peers, suppliers, and customers, language proficiency increases labour productivity and, therefore, earnings (Chiswick and Miller, 2002). Second, host country language proficiency is complementary with other productivity-enhancing forms of human capital, particularly education; knowing the language(s) of the destination country increases the utilization of education in the workplace (Bleakley and Chin, 2004; Chiswick and Miller, 2002; Park, 1999). Third, language proficiency influences occupational opportunities. Immigrants with low levels of language proficiency may cluster in jobs where destination-language proficiency does not matter for job performance, even though they may be overqualified for these jobs in terms of their other human capital endowments such as educational achievements (Boyd, 1999; Kossoudji, 1988).

Empirical studies confirm that destination-language proficiency is related to labour force participation and an important determinant of earnings among immigrants in Australia (Chiswick and Miller, 1995), Germany (Dustmann and Van Soest, 2002), Israel (Berman, Lang, and Siniver, 2003; Remennick, 2004), the United Kingdom (Dustmann and Fabbri, 2003; Shields and Price, 2002), and the United States (Bellante and Kogut, 1998; Bleakley and Chin, 2004; Carnevale, Fry and Lowell, 2001; Chiswick and Miller, 2002; Park, 1999). In Canada, recent research on the deteriorating earnings of recent immigrants includes language as a variable, finding lower 
earnings for immigrants whose mother tongue is not English and/or French (Aydemir and Skuterud, 2005; Frenette and Morissette, 2005). Other Canadian wage determination studies also include mother tongue or knowledge of official languages as variables; however, to date only two studies exist where the relationship between immigrant linguistic skills and earnings in Canada are the focal point (Chiswick and Miller, 2003; Pendakur and Pendakur, 2002). Both studies analyze the 1991 census, finding that earnings are higher for those with English/French language skills compared to those who do not know at least one of Canada's two official languages.

\section{Language and Earnings in the 21st Century}

Building on past research, we present evidence that differential earnings relative to levels of language proficiency continue to be part of the immigrant experience in the early 21 st century. Our research goes beyond current economic analyses of immigrants in three ways. First, we scale levels of host country language proficiency into a more detailed measure than used in earlier studies, which measured high language proficiency as English/ French mother tongue or official language knowledge. Second, using ordinary least square regression techniques (OLS) we extend classic models of economic returns to language by showing the mediating role of occupations in such models. Third, in addition to ordinary least square regression techniques (OLS), we employ quantile regression techniques to highlight differences that exist through the entire earnings distributions of immigrants, not just at the mean.

Our analysis is based on data in the 2001 Census Public Use Microdata File (PUMF) on Individuals (2006 census data were not available at the time of writing this paper). This 2001 data set is compiled from a $2.7 \%$ sample of the population enumerated in the census. The population of interest is the foreign-born permanent residents of Canada, who are between the ages of 25-54 and thus of prime labour force age, and who do not live in the Atlantic Provinces, the territories, or in Nunavut. The decision to study only the immigrant population outside of the Atlantic provinces and territories derives from the coding practices used by Statistics Canada to preserve confidentiality in publicly released microdata sets by aggregating information on the population living in these areas.

The dependent earnings variable is defined as the weekly wage and self-employment earnings received by those respondents in 2000 who also indicated that they had worked one week or more during that year. Because earnings are either prorated or not reported for immigrants entering during 2000 or 2001, the analysis is for those who entered Canada prior to 
2000. The unit of analysis is actual weekly wages rather than logged weekly wages preferred by economists (see Hodson, 1985 for a comparison of the two methods). Using actual dollars demonstrates the absolute magnitude of the "cost" of knowing or not knowing destination country language(s); in multivariate regression, estimates can be understood as dollar returns to various levels of linguistic proficiency.

The main independent variable of interest, level of language proficiency, extends an earlier scale of language proficiency derived from census questions about mother tongue, home language, and official language knowledge (Boyd, 1999; Boyd, DeVries, and Simkin, 1994). In the 2001 census of Canada, respondents were asked to indicate their mother tongue(s) (defined as the language that respondents first learned at home in childhood and still understand); the language(s) spoken by respondents most often at home; the additional language(s) spoken regularly by respondents in the home; and whether they speak English or French well enough to conduct a conversation. When responses are combined, the resulting measure of language proficiency represents the extent to which one or more official languages is understood and used (or not used) in different contexts, or domains. Chart I indicates the coding algorithm. Level 1 represents the highest level of proficiency in one or both of Canada's official languages: respondents have English and/or French as their mother tongue, use it/them most often at home, and can converse in English and/or French. At the lowest level of English/ French proficiency are immigrants who indicate that their mother tongue, their home language used most often or regularly, and their conversational abilities are only in languages other than English and/or French.

As shown in Figure 2, average 2000 weekly earnings vary by these levels of language proficiency. Immigrant women who are categorized at level 1 (mother tongue(s), home language(s), and ability to converse are all English and/or French) have average earnings that are 1.6 times the earnings of immigrant women who are at level 5, the lowest level of proficiency in English and/or French. Similarly, immigrant men who are categorized at level 1 have average weekly earnings that are 1.8 times greater than those

Chart 1. The Construction of Levels of Language Proficiency, Canada 2001 Census of Population

\begin{tabular}{llclc}
\hline \hline $\begin{array}{c}\text { Mother } \\
\text { Tongue }\end{array}$ & $\begin{array}{c}\text { Home Language } \\
\text { Used Most Often }\end{array}$ & $\begin{array}{c}\text { Home Language } \\
\text { Used Regularly }\end{array}$ & $\begin{array}{c}\text { Conversational Knowledge } \\
\text { of Official Language(s) }\end{array}$ & $\begin{array}{c}\text { Language } \\
\text { Proficiency Level }\end{array}$ \\
\hline $\begin{array}{c}\text { English/French } \\
\text { English/French }\end{array}$ & English/French & Nonofficial & Nonofficial & I \\
Nonofficial & English/French & & English/French & $\mathrm{V}$ \\
Nonofficial & Nonofficial & English/French & English/French & $\mathrm{I}$ \\
Nonofficial & Nonofficial & Nonofficial & English/French & $\mathrm{II}$ \\
Nonofficial & Nonofficial & & Nonofficial & $\mathrm{IV}$ \\
\hline
\end{tabular}

Source: www12.statcan.ca/english/census01/Products/Reference/dict/appendices/app016.pdf 
Figure 2: Average Weekly Earnings in 2000 for Immigrants, by Sex and Language Proficiency, Canada, 2001

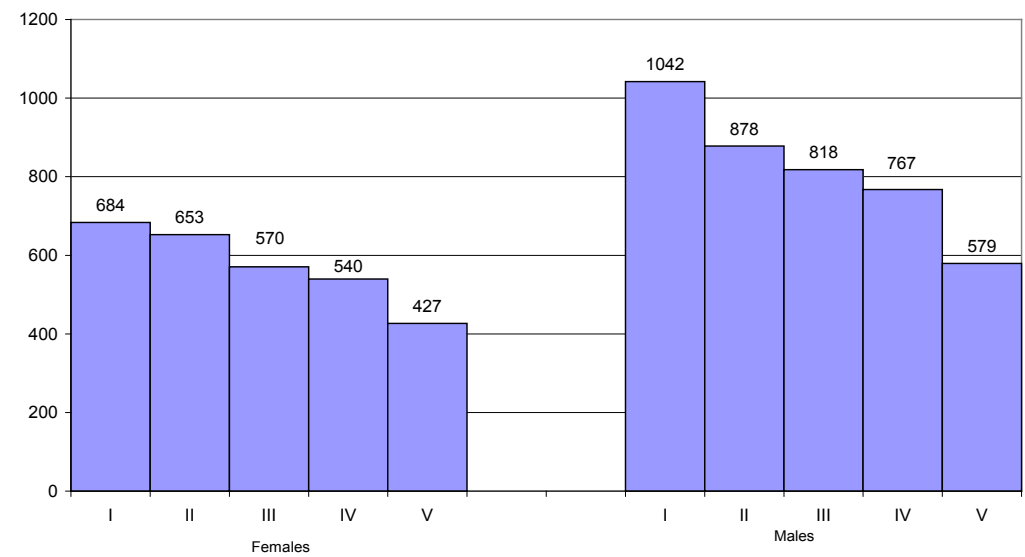

received by men with level 5 proficiency. Figure 2 also demonstrates the well known gender gap in earnings between women and men, with women earning less.

Table 1 presents the distribution of the immigrant population by levels of language proficiency. If levels 4 and 5 are considered to represent low levels of proficiency, then at least one-third of Canada's immigrant wage earners have poor English-French proficiency. Language proficiency levels also are associated with other variables known to influence earnings. As shown in Table 1, immigrants who have lower levels of English/French language proficiency also have higher percentages without high school diplomas and higher percentages who are members of visible minority groups. They are more likely than immigrants with high levels of proficiency to be living in Canada's major gateway cities (Montreal, Toronto, and Vancouver); to have fewer years of experience in Canada, which reflects recent arrival; and they are far less likely to be employed in the managerial, professional, semiprofessional, and technical occupations.

In order to illuminate the benefits and costs of English/French language skill levels, multivariate analysis controls for these variables: place of residence, marital status, visible minority status, education, length of potential experience outside of Canada and within Canada, and type of occupations held. Ordinary least squares (OLS) regression results appear in Table 2. Significance levels for coefficients are produced by first applying the population weight to the PUMS sample in order to take the sample design into account, and then downweighting by a factor that reduces the estimated population to the size of the original sample. Three models are employed, 
Table 1. Selected Socioeconomic Characteristics for Immigrants (25-54) who Worked at least one Week in 2000, by Language Proficiency and Sex, Canada, 2001 (excluding Atlantic provinces)

\begin{tabular}{|c|c|c|c|c|c|c|}
\hline & \multicolumn{6}{|c|}{ Language Proficiency (a) } \\
\hline & Total & 1 & II & III & IV & V \\
\hline \multicolumn{7}{|c|}{ Population estimates } \\
\hline Females & 670,140 & 166,720 & 144,848 & 137,151 & 193,323 & 27,679 \\
\hline Males & 705,507 & 153,488 & 143,642 & 157,456 & 226,666 & 24,254 \\
\hline \multicolumn{7}{|c|}{ Percentage distribution } \\
\hline Females & 100.0 & 24.9 & 21.6 & 20.5 & 28.8 & 4.1 \\
\hline Males & 100.0 & 21.8 & 20.4 & 22.3 & 32.1 & 3.4 \\
\hline \multicolumn{7}{|c|}{ Percentages with less than high school diploma ${ }^{(b)}$} \\
\hline Females & 17.1 & 11.0 & 10.2 & 15.3 & 21.5 & 68.6 \\
\hline Males & 17.9 & 11.5 & 11.3 & 14.9 & 23.5 & 65.5 \\
\hline \multicolumn{7}{|c|}{ Percentages who are visible minorities } \\
\hline Females & 65.2 & 45.8 & 63.8 & 69.3 & 77.2 & 85.2 \\
\hline Males & 64.6 & 43.7 & 60.4 & 71.2 & 75.1 & 81.4 \\
\hline \multicolumn{7}{|c|}{ Percentages living in Montreal, Toronto, Vancouver } \\
\hline Females & 68.5 & 62.0 & 63.8 & 70.7 & 74.6 & 78.4 \\
\hline Males & 69.6 & 62.2 & 65.7 & 71.1 & 75.0 & 79.6 \\
\hline \multicolumn{7}{|c|}{ Average years of Canadian experience } \\
\hline Females & 13.0 & 16.1 & 14.2 & 11.8 & 10.8 & 10.3 \\
\hline Males & 12.6 & 15.6 & 14.2 & 11.3 & 10.6 & 9.9 \\
\hline \multicolumn{7}{|c|}{$\begin{array}{l}\text { Percentages in managerial, professional, } \\
\text { semiprofessional, and technical occupations }\end{array}$} \\
\hline Females & 32.5 & 40.3 & 37.1 & 30.9 & 26.9 & 8.2 \\
\hline Males & 40.0 & 47.7 & 45.4 & 40.3 & 34.1 & 14.2 \\
\hline \multicolumn{7}{|c|}{ Average weekly earnings in 2000} \\
\hline Females & 602 & 684 & 653 & 570 & 540 & 427 \\
\hline Males & 855 & 1042 & 878 & 818 & 767 & 579 \\
\hline
\end{tabular}

each specific for women and for men: the first regresses weekly earnings on the levels of language proficiency without any controls for variables associated with language proficiency and with earnings. The reference group consists of those permanent residents who have the highest level of English/French proficiency (Level 1). The second model controls for the differences that exist between language levels with respect to place of residence, visible minority status, educational attainment, marital status, years of potential Canadian experience, and years of potential experience outside Canada. The experience variables are calculated from the potential experience measure widely used in economics and defined as age-(education +5$)$; potential experience is then divided into portions of experience occurring outside and inside Canada, using age and year of immigration variables to calculate ages of arrival. The coefficients for model 2 (Table 2, panel 1) indicate what the weekly earnings would be, relative to those at the highest levels of language proficiency, if the subpopulations in all proficiency levels had the same distributions with respect to the control variables. The third model includes a control for occupational location, measured in 12 categor- 
ies ranging from managers to manual occupations. In addition to deviations from the reference group (level 1 proficiency), results are also expressed as deviations from the overall mean (Table 2, second panel), using a transformation procedure described by Andrews, Morgan, and Sonquist (1973). When added to the overall means of $\$ 602$ for women and $\$ 855$ for men in Table 1, weekly wages can be calculated (Table 2, third panel)

Regardless of the mode of expression (deviations from level 1, deviations from the mean, or weekly averages specific to each language proficiency level), the multivariate results shown in Table 2 generate three conclusions. First, lower levels of language proficiency are associated with

Table 2. Regression Coefficients, Deviations from the Mean, and Weekly Earnings of Immigrants, Age 25-54, Working at least one Week in 2000, by Sex and Language Proficiency, Canada 2001 (excluding Atlantic Provinces, Territories, and Nunavut)

\begin{tabular}{|c|c|c|c|c|c|c|}
\hline & \multicolumn{3}{|c|}{ Females } & \multicolumn{3}{|c|}{ Males } \\
\hline & $\begin{array}{c}\text { Model } \\
1^{(c)}\end{array}$ & $\begin{array}{c}\text { Model } \\
2^{(b)}\end{array}$ & $\begin{array}{c}\text { Model } \\
3^{(c)}\end{array}$ & $\begin{array}{c}\text { Model } \\
1^{(a)}\end{array}$ & $\begin{array}{c}\text { Model } \\
2^{(b)}\end{array}$ & $\begin{array}{c}\text { Model } \\
3^{(c)}\end{array}$ \\
\hline \multicolumn{7}{|c|}{$\begin{array}{l}\text { Language proficiency } \\
\text { level(d) }\end{array}$} \\
\hline 1 & (rg) & (rg) & (rg) & (rg) & (rg) & (rg) \\
\hline$\|$ & -30.77 & -37.89 & -22.44 & $-164.23^{\star \star \star}$ & $-162.00^{\star \star \star}$ & $-145.95^{\star \star \star}$ \\
\hline III & $-113.13^{\star \star \star}$ & $-106.42^{\star \star \star}$ & $-80.84^{\star \star \star}$ & $-223.98^{\star \star \star}$ & $-184.31^{\star \star \star}$ & $-158.54^{\star \star \star}$ \\
\hline IV & $-143.71^{\star \star \star}$ & $-109.39^{\star \star \star}$ & $-83.91^{\star \star \star}$ & $-274.59^{\star \star \star}$ & $-183.63^{\star \star \star}$ & $-153.20^{\star \star \star}$ \\
\hline V & $-256.95^{\star \star \star}$ & $-118.26^{\star \star}$ & $-89.27^{\star}$ & $-462.90^{\star \star \star}$ & $-227.41^{\star \star \star}$ & $-189.25^{\star \star \star}$ \\
\hline \multicolumn{7}{|c|}{$\begin{array}{l}\text { Deviations from overall } \\
\text { mean(e) }^{(e)}\end{array}$} \\
\hline I & 81.95 & 66.48 & 49.34 & 187.56 & 140.93 & 120.82 \\
\hline$\|$ & 51.18 & 28.59 & 26.90 & 23.33 & -21.07 & -25.13 \\
\hline III & -31.18 & -39.95 & -31.50 & -36.42 & -43.38 & -37.71 \\
\hline IV & -61.77 & -42.91 & -34.57 & -87.03 & -42.70 & -32.37 \\
\hline V & -175.00 & -51.79 & -39.93 & -275.34 & -86.48 & -68.42 \\
\hline \multicolumn{7}{|c|}{ Mean weekly earnings ${ }^{(f)}$} \\
\hline I & 684 & 668 & 651 & 1042 & 995 & 975 \\
\hline$\|$ & 653 & 630 & 628 & 878 & 833 & 829 \\
\hline III & 570 & 562 & 570 & 818 & 811 & 817 \\
\hline IV & 540 & 559 & 567 & 767 & 812 & 822 \\
\hline V & 427 & 550 & 562 & 579 & 768 & 786 \\
\hline \multicolumn{7}{|c|}{$\begin{array}{l}\text { Note: }{ }^{*} \mathrm{p}<0.05 ;{ }^{* *} \mathrm{p}<0.01 \text {; }{ }^{* \star} \mathrm{p}<0.001 \\
\text { (a) Gross effects, no control variables in the model. } \\
\text { (b) Net of visible minority status (Chinese, South Asian, Black, other visible minorities, nonvisible minorities); edu- } \\
\text { cational level (no HS diploma, HS diploma or trade certificate, postsecondary schooling, bachelors degree or } \\
\text { higher); place of residence (Montreal, Toronto, Vancouver, other CMAs, other areas); marital status (single, mar- } \\
\text { ried, common-law, other); Canadian experience, Canadian experience squared, experience outside Canada, } \\
\text { outside experience squared. } \\
\text { (c) Net of factors listed in (b) and net of occupation, coded into } 12 \text { categories. } \\
\text { (d) See Chart } 1 . \\
\text { (e) Transformed into deviations from the population means in Table 1, column 2. See Andrew, Morgan, and Sonquist } \\
\text { (1973). } \\
\text { (f) Deviations added to the population means in Table 1, column 2. } \\
\text { (rg) Reference group }\end{array}$} \\
\hline
\end{tabular}


declines in earnings. In real life, for those working in 2000, a wage gap of $\$ 257$ exists between the average wages for women with very high and with very low levels of proficiency; for men the gap is $\$ 463$, reflecting the greater variability and range of their earnings compared to women. These gaps partly reflect compositional differences between those with different linguistic proficiency levels. When these are taken into account, gaps in earnings between levels I and V drops to $\$ 118$ for women and $\$ 227$ for men (Table 2, columns 2 and 5). Stated differently, about 54\% of the original gap of $\$ 257$ for women (calculated as $1-(118.26 / 256.95)$ ) and $51 \%$ of the original gap of $\$ 463$ for men reflect the influence of other factors that are associated both with language proficiency and with earnings - factors such as levels of educational attainments, location, and visible minority status. Insights into the gaps between level I and other levels of English/French proficiency can be reached in a similar manner.

Second, in Model 2, regression coefficients, the related deviations from the mean and mean weekly earnings show that even after taking other factors into account the relationship between levels of language proficiency and earnings is positive; that is, immigrants who have high levels of host country linguistic proficiency have higher earnings while those who lack knowledge of English and/or French have the lowest earnings. While the cost of very low levels of proficiency may seem small ( $\$ 118$ for women and $\$ 227$ for men), over 52 weeks the difference becomes $\$ 6,136$ and $\$ 11,804$ annually for women and men. After 10 years, the maximum projected "cost" of being in the lowest level of proficiency compared with the highest level stands at $\$ 61,360$ and $\$ 118,040$ for women and men. These figures suggest both that real gains in earnings are to be obtained if immigrants can improve their levels of proficiency and that the sooner such improvements occur the greater the reduction in potential earnings loss, relative to those fluent in English and/or French.

Within an economic framework, the earnings found in model 2 represent the impact of language proficiency on earnings after taking other productivity enhancing factors into account. From a sociological perspective, however, the process by which language proficiency affects earnings occurs in a sequence. Language skills influence what kinds of jobs immigrants hold, and jobs in turn influence the pay rates paid to workers. According to this perspective, ${ }^{2}$ occupational location is an intervening variable between language proficiency and earnings. Including occupational location in a

2. Conversely, much of the economic literature eschews conceptualizing occupational locations as intervening variables, arguing either that occupations are endogenous to the modeling of language skills as a form of human capital and should be excluded, or that controlling for occupations indicates the impact of linguistic variations in earnings within occupations. 
regression analysis, as is done in Model 3, indicates the residual impact of language proficiency on weekly earnings that remains after taking into account the effect of language skill on occupational location and the effect of occupational location on wages. Our third finding derives from comparisons between Model 2 and Model 3; these comparisons show that the mediating role of occupations accounts for approximately $25 \%$ and $17 \%$ of the wage gaps between proficiency levels I and V that are found in Model 2 for women and men respectively (for example, $1-(89.27 / 118.26)=.245$ for women). In sum, the allocating impact of language proficiency on occupational location also underlies the lower earnings for immigrants who lack proficiency in English and/or French.

The previous discussion on the "costs" of low language proficiency among immigrants relies on multivariate techniques that focus on average earnings. However, it is unlikely that workers employed in low wage jobs would experience the same earnings returns from knowing (or not knowing) English and/or French as workers who are in high wage jobs. This supposition rests on the nature of work in low and high paying jobs which differ with respect to occupational and industrial composition, wage variability, seasonality and/or security of employment, and the existence of union or bureaucratic guidelines for pay and promotion. Differently put, wages for nighttime office cleaners are both lower and less likely to vary substantially by language skills compared to wages paid in knowledge creation jobs. If this is the case, then the costs of poor host language proficiency could be higher than suggested by traditional analytical methods that focus on the mean of the earnings distribution, given that Canada now actively seeks skilled immigrants.

In order to determine if the impact of language proficiency on earnings differ throughout the earnings distributions for women and men, quantile regression analysis is also performed. Quantile regression examines the relationship between independent variables and the conditional quantile of the dependent variable (Koenker and Bassett, 1978; Koenker and Xiao, 2002). It provides a full picture of the conditional distribution of the dependent variable $(\mathrm{Y})$ given specific values of independent variables $(\mathrm{X})$, especially when researchers are interested in different points (other than mean) of the conditional distribution. In the case of language proficiency, quantile regression shows if the dollar gap in earnings returns to levels of language proficiency vary at different parts of the earnings distribution.

Coefficients are presented in Table 3 for the 25th, 50th (median) and 75 th deciles of the earnings distributions. As was the case for OLS, earnings models are constructed separately for women and men, and significance levels are based on sex-specific downweighting of the female and male immigrant population. The first quantile regression model with only English/ 
French proficiency levels shows that the earnings disadvantages associated with low levels of language proficiency, compared to immigrants with the highest level of proficiency, depend on where in the income distribution the discrepancies are being measured (Model I in Table 3). For women and men alike, the relative penalty or "cost" of not being proficient in English and/ or French is lowest for those in the bottom quarter of the earnings distribution; it is highest for those in the top $25 \%$ of the earnings distribution (Table 3 , column 1 versus column 3 ). While the correspondence is not $100 \%$, the upper part of an income distribution often reflects earnings paid to better educated workers holding well paying jobs, including managerial and professional occupations. As a result, the 75th decile results suggest that penalties for poor language skills may be greatest for skilled and highly skilled workers.

In Models II and Model III, we further control for socioeconomic variables, human capital variables (education and experience outside and in Canada), and occupational location. For both females and males, the earnings penalties associated with language proficiency diminish after controlling for place of residence, visible minority status, human capital variables,

Table 3. Regression Coefficients, Deviations from the Mean, and Weekly Earnings of Immigrants, Age 25-54, Working at least One Week in 2000, by Sex and Language Proficiency, Canada 2001 (excluding Atlantic Provinces, Territories. and Nunavut)

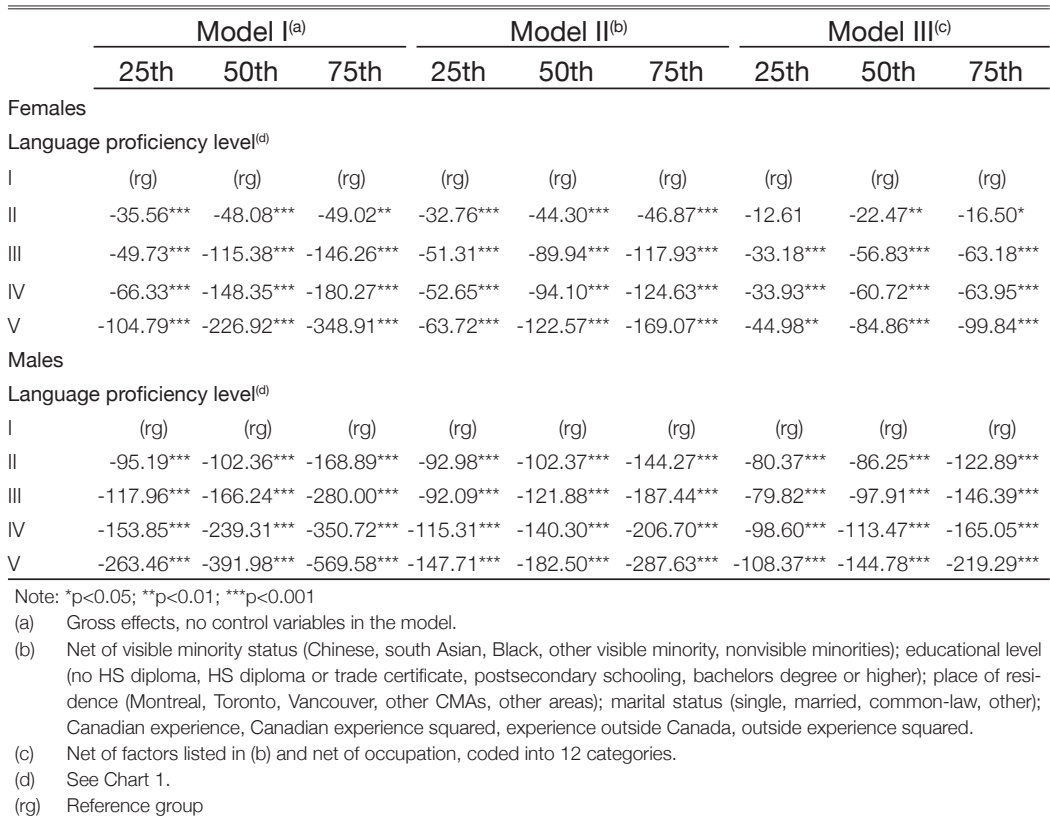


and occupation, indicating the mediating effects of these factors on earnings. Nonetheless, the patterns of language effects across different language groups remain very consistent. For all models, the cost of having low level language skills is most severe for immigrants at the higher ends of the earnings distributions. Immigrant men more than women face higher penalties throughout, and especially at the upper quartile of their earnings distribution; this is consistent with higher male earnings (see Table 1) and the greater range of male immigrant earnings.

\section{What to Do? State-funded Language Policies}

Our research demonstrates that immigrants with poor host country language skills earn less than those who are highly proficient in English and/or French even after other characteristics associated with language skills and earnings have been taken into account. Succinctly put, inequalities in language skills are linked to inequalities in immigrant earnings. Our analysis also shows that the earnings gaps between those with high and low levels of English/ French language proficiency are greatest for immigrants in well paying jobs. This latter finding adds to current knowledge regarding immigrant labour market difficulties, particularly among the better educated. In their analysis of 2006 census data, Galarneau and Morissette (2008) find that knowledge of languages other than English or French and country of origin are important factors underlying the increasing percentages of university educated immigrants who are underemployed, working in occupations for which they are overeducated. Other studies point to the deteriorating relative earnings of recent immigrant cohorts. Our quantile regression analysis suggests that even among those who have jobs with high earnings, those with low language proficiency levels will earn substantially less than their linguistically fluent counterparts and that this gap is larger than observed in lower paying jobs. In sum, even when immigrants obtain better paying jobs, they will experience a high penalty for poor language proficiency.

Given the earnings costs associated with low levels of language proficiency, what steps are to be taken and by what agents? A laissez-faire position maintains that nothing need be done - if immigrants realize they stand to gain from learning the destination country language(s) they will invest in themselves, taking the time, energy, and money to do so. An alternative perspective argues that governments are in the business of providing a level of welfare for its citizens and that permanent residents are part of the population that receives social and civic citizenship rights. The expectation then is that governments will take actions that have direct impacts on the welfare of its people, including immigrants. These efforts of governments 
may include two strategies: offering English/French language training to migrants already in Canada and fine tuning immigration policy to increase the admission of those with high levels of language proficiency.

With respect to the first strategy, the Canadian federal government has a long history of funding English-French language training programs for immigrants as part of its settlement activities. The federal role in language training programs started in 1947 (McDonald et al., 2008). Serious activity began in the late 1960s and early 1970s, although the rationales, target populations, and types of programs differed over time (see Boyd, 1992; Boyd, DeVries and Simkin, 1994 for a review of programs prior to 1992). During the past forty years, funding and related programs that are explicitly targeted at workers or those destined for the labour force have waxed and waned. During the 1970s and 1980s, language training offered under the Canadian Job Strategy programs had a much larger funding base than programs focused on language learning to facilitate general settlement (Boyd, 1992). Today, with one exception discussed below, federal language training is offered as a settlement strategy with little attention to targeting those in the labour force. Thus, attempts to improve the language proficiencies of the employed must look to these general settlement programs or rely on the self-funded efforts of immigrants themselves.

What are the current language training programs and what are their likely impacts for immigrant wage earners? The Language Instruction for Newcomers to Canada (LINC) is the current federally funded program specifically targeted at language instruction; it funds full- and part-time classes for eligible applicants, largely provided through nongovernmental organizations. Participants must be landed immigrants with permanent residency cards, aged 18 years or older; they are newcomers, typically arriving within the past three to five years and before they become citizens; they must not speak English or French as their first language and they must undergo language assessment - testing their listening, speaking, reading, and writing skills - to determine the level of instruction they require (Citizenship and Immigration Canada, 2004). Language training is provided in a variety of ways (e.g., full time, part time, home study, distance learning, training at/near work site, itinerant teachers serving small communities). Provincial governments also fund language training programs; over the years the role of provinces in settlement activities has grown, partly reflecting federal-provincial agreements (Citizenship and Immigration, 2007b). Federal agreements with Manitoba and British Columbia transfer federal funds and responsibility for settlement services to those provinces. Under the Canada-Quebec Accord, Quebec gets a significant share of settlement funding provided by the federal government for the sole administration by Quebec 
government officials (Citizenship and Immigration, 2007a, 2007b).

Regrettably, any policy evaluation attempts to comprehensively assess the numbers served and the effectiveness of general language training programs such as LINC are nullified by at least three factors: 1) the existence of federal and multiple provincial players, each funding diverse programs; 2) the general paucity of specific language training program descriptions in publicly available federal or provincial documents; and 3) the discussion in publicly available government documents of settlement funding allocations rather than impact or cost-benefit analyses. Discussions that refer to levels of funding rather than to clients served prevent calculating estimates regarding coverage. This information void appears to be common in the settlement services realm. A 1998 report laments

Not only are we unable to determine whether settlement funds are spent in an effective manner ... but we have no information on who accesses these services, which would then allow us to determine whether these particular expenditures contribute in a positive or anticipated manner to the integration process of the individual immigrant. (Citizenship and Immigration Canada, 1998)

Despite these severe information constraints, we suggest that LINC and related general settlement-focused language training programs will have little impact on improving the language skills of immigrants who are currently in Canada and who are in the labour force. First, language training programs offered as part of settlement initiatives are general language learning programs; because they are not specifically targeted at immigrants who are in the labour force, such programs may not provide workplace relevant language skills. Second, when offered as part of settlement activities, the catchments are small. A 2004 evaluation of LINC indicated that approximately 20\% of newcomers participate in LINC (Citizenship and Immigration Canada, 2004). Third, the federally funded LINC program is targeted to newcomers, those arriving within the past three to five years. Yet, unpublished census data show that some immigrants with low levels of English/French proficiency have been in Canada for many years. Fourth, by its own description, Language Instruction for Newcomers to Canada "provides basic training" (Citizenship and Immigration Canada, 2005b) which refers to instruction from Canadian Language Benchmarks (CLB) levels 1-6/7, or Standards linguistiques canadiens (SLC) levels 1-6/7 for French. Until 2005, the training covered only levels $1-5$, leaving successful participants capable of following simple tasks and instructions but not much more (see: Centre for Canadian Benchmarks, no date, a). With such training it is unlikely that participants would be speaking English or French in multiple sites, including home, and would be considered "fluent" in their grasp of their new language(s). 
Do language training initiatives exist that target immigrants who are either in the labour force or seeking employment? This question gains additional importance since language skills associated with successful initial settlement cannot be automatically equated with those needed for successful labour market integration. As CIC observes "[w]hile most newcomers destined for the Canadian labour force have adequate conversational language skills when they arrive, many employers report gaps in recent immigrants' language skills and vocabulary in the workplace" (Citizenship and Immigration Canada, 2005a).

The answer to our question is a much qualified "yes." In 2004, Citizenship and Immigration launched the Enhanced Language Training (ELT) initiative with the objective of funding labour market levels of language training. The focus is on providing Canadian Language Benchmarks (CLB) levels 7-10 to immigrants who seek to enter the labour force. Language training is at CLB levels 7-10 in larger centres and at 1-10 in smaller centres where no other language training infrastructure exists (Canada, n.d., 2008). Cast as an interagency project, the two main federal players are Citizenship and Immigration Canada and Human Resources and Social Development Canada (HRSDC). Two requirements are 1) ELT projects are funded through contribution agreements with stakeholders, including provinces and territories, nongovernmental organizations, employers, educational institutions, and community agencies serving immigrants; and 2) that ELT projects include employment supports and bridge-to-work activities such as access to internships and work placements as well as mentorship services for adult immigrants (Citizenship and Immigration Canada, 2005a).

The Enhanced Language Training initiative targets skilled workers (Citizenship and Immigration Canada, 2007a); it thus has the potential to deal with the paradox that highly trained immigrants are not necessarily highly proficient in Canada's official languages, or lack the workplace vocabularies that employers and clients demand. However, while this initiative targets immigrant workers who might hold well paying jobs, three caveats exist. First, the target population is recent immigrants, not those who also have been in Canada for some years. Second, ELT is not designed to remedy a basic lack of language skills. To be eligible for ELT funded programs, immigrant workers must already be proficient in English and/ or French at the Canadian Benchmark or Standards linguistiques canadiens level of 6, which, while not highly advanced, goes beyond rudimentary knowledge (see Centre for Canadian Benchmarks, no date, a). Third, as is true for LINC, it is not clear how many immigrants will be reached by the English Language Training initiative. Although a number of projects exist (Citizenship and Immigration Canada, 2004; 2005b), little information is 
publicly available about the numbers served or the impact of the program. In keeping with past practices of reporting inputs, a 2005 CIC Backgrounder report states a federal funding level of $\$ 20$ million targeted at providing higher levels of language training to up to 20,000 immigrants a year seeking to join the labour force (Citizenship and Immigration Canada, 2005a).

In addition to settlement initiatives, recent alterations in immigration policy contain two mechanisms that potentially could improve the English/ French language proficiency of highly skilled immigrant workers who are likely to be employable in high paying jobs in the future. First, as discussed in the earlier section on why language proficiency matters, increased points are now given to English/French language competency in the point system adopted with IRPA in 2002 and applied to principal applicants in the skilled worker class. This and improved testing of English and French proficiency will ensure that future flows of high skilled labour have higher levels of language proficiency, indirectly improving the language proficiency profile of those workers in well paying jobs. However, it should be noted that these changes will not necessarily improve the linguistic proficiency of all workers since it is inaccurate to assume that all are destined to work or are highly skilled. Spouses and dependents make up over half of those recently admitted in the skilled worker category and they are not assessed on the point system. Principal applicants in the skilled worker class represent slightly over $20 \%$ of all persons admitted as permanent residents in the period 1998-2007 but this figure masks a downward trend over the 10 year period. In fact, in 2007 only $17 \%$ of all immigrants to Canada were assessed on the full skilled worker points system (Citizenship and Immigration Canada, no date).

Second, a new class was created recently to recruit persons who are already in Canada on a temporary basis. On September 17, 2008, the Canadian Experience Class (CEC) was established by formally amending the Immigration and Refugee Protection Act. The CEC is a new avenue of immigration for certain temporary foreign workers and foreign student graduates with professional, managerial and skilled work experience. This new admissions class is designed to take advantage of highly skilled workers who are already in Canada as well as foreign students who recently received degrees, diplomas, or certificates from Canadian postsecondary institutions . In addition to meeting Canadian experience and occupational criteria, applicants must undergo language tests to demonstrate that their language abilities are in keeping with their occupations.

As is the case for changes associated with IRPA, creating a new class of entry with its attentiveness to language skills will not remedy the situation for immigrants who have been admitted in the past or who continue to be admitted in the family and refugee classes or as family members in the 
skilled worker class. Additionally, two features suggest a small impact of the new Canadian Experience Class on the overall English/French proficiency of Canada's immigrant workforce and on the language skills of those in high paying jobs. First, although Citizenship and Immigration Canada anticipates the admission of 5,000 to 7,500 persons in this class for 2009, so far the take-up rate has been slow; by late fall 2008 only 210 applications had been received (Keung, 2008). Possible reasons for the unexpected low numbers include the downturn in the Canadian economy, with the result that applicants see themselves as competing with newly unemployed Canadians, and the requirement that applicants undergo a language proficiency test. Second, language skills demanded for admission in the Canadian Experience Class are moderate at best. As stated in The Gazette (Canada, 2008), admissions in the CEC will be limited to Skill Type 0 Management Occupations, Skill Level A (professional occupations), or Skill Level B (technical occupations and skilled trades) of the National Occupation Classifications (NOC). Applicants with qualifying Canadian work experience at NOC 0 or A will need to demonstrate "moderate proficiency" in French or English while applicants with qualifying Canadian work experience at NOC B will need to demonstrate "basic proficiency" in French or English that corresponds to the Canadian Language Benchmarks. According to the Centre for Canadian Language Benchmarks (no date, b), many persons who have acquired moderate proficiency are ready to take postsecondary academic schooling and may have levels of proficiency that will enhance their work; the use of language skills at work is not mentioned for those with basic levels of proficiency; instead they are described as having a range of abilities needed to communicate in common and predictable settings to meet basic needs and to carry out everyday activities.

\section{Conclusion}

Starting with regulatory changes in 1962 and in 1967, and enshrined in the Immigration Act, 1975, Canada removed national origins as a criterion of admissibility. Instead, entry into Canada as a permanent resident rests on principles of family reunification, humanitarian concerns, and economic contributions. Not coincidently, since the mid-1960s, the origins of immigrant flows to Canada have shifted away from Europe to Asia and to a lesser extent Latin America, the Caribbean, and Africa. Many of these "new" immigrants to Canada now come from countries or regions where the main language is not one of Canada's charter languages (English and French). These altered linguistic characteristics of immigrants focus attention on the 
relationship between linguistic proficiency in the host country language and the social and economic integration of immigrants.

Using a five-level scale of English/French language use, our analysis of 2001 census data for the population age 25-54 confirms the positive association between proficiency in Canada's charter language(s) and immigrant earnings. Compared to permanent residents who are highly proficient in English and/or French (English and/or French is mother tongue, used most often at home and English and/or French used in conversation), those with lower levels of proficiency have lower weekly earnings. In 2000, women who had the highest levels of proficiency earned on average \$684 per week while their counterparts with no knowledge of English and/or French earned \$427, a difference of \$257. Similar differentials are found for immigrant men; those with the highest level of English/French proficiency (level I) earned on average $\$ 1,042$ while those with the lowest level (level V) earned $\$ 579$. Some of these differences reflect age, location, education, marital, visible minority, experience, and occupational characteristics that exist for the language proficiency populations. However, differentials persist after statistically adjusting for the influences of these compositional differences. Our research also reveals that the relative advantage (or disadvantage) of English/French language proficiency is higher for those in the top quarter of the earnings distribution; greater penalties exist for immigrants with low levels of language proficiency at the upper end of the earnings distribution than for those working in low paying jobs.

Our overview of federal language training initiatives highlights two programs that have the potential to improve immigrant linguistic skills and thus improve earnings: Language Instruction for Newcomers (LINC) and Enhanced Language Training (ELT). While these policy efforts clearly demonstrate that the Canadian federal government, along with provinces, is concerned about the language skills of immigrants, these initiatives are not available to everyone who requires improved language proficiency. If the English/French language skills of immigrants who are already in Canada and in the labour force are to be increased, then additional policy attention with supplementary programs for language training is required.

As noted at the outset, language training policies are part of migrant policies, which have as their raison d'être the integration of newcomers into host societies. In addition to these policies, destination countries can reduce the need for select migrant integration policies by fine tuning immigration regulations that determine who shall be admitted (Boyd, 1999). The CIC Annual Report to Parliament, 2007 signalled that the new selection grid introduced by Immigration and Refugee Protection Act (IRPA) in June 2002 is expected to have a positive impact on the long-term ability of 
skilled workers to be economically integrated in the face of changing labour market circumstances. An evaluation is to be completed in 2008-2009, focusing on changes introduced by IRPA and on the economic outcomes for newcomers during the first year of settlement. Our paper indicates the importance of including language proficiency in this and future assessments.

\section{References}

Andrews, F.M., J.N. Morgan, and J.A. Sonquist. 1973. Multiple Classification Analysis, 2nd edition. Ann Arbor, MI: Survey Research Center, University of Michigan.

Aydemir, A. and M. Skuterud. 2005. "Explaining the deteriorating entry earnings of Canada's immigrant cohorts, 1966-2000." Canadian Journal of Economics 38(2):641-672.

Bellante, D. and C.A. Kogut. 1998. "Language ability, US labor market experience and the earnings of immigrants.” International Journal of Manpower 19(5): 319-330.

Berman, E., K. Lang, and E. Siniver. 2003. "Language-skill complementarity: Returns to immigrant language acquisition.” Labour Economics 10(3):265-290.

Bleakley, H. and A. Chin. 2004. "Language skills and earnings: Evidence from childhood immigrants." Review of Economics and Statistics 86(2):481-496.

Boyd, M. 1992. "Gender issues in immigration and language." Pp. 305-372 in Barry Chiswick, ed., Immigration, Language and Ethnicity: Canada and the United States. Washington, DC: The AEI Press.

- 1999. “Integrating gender, language, and race.” In S.S. Halli and L. Driedger, eds., Immigrant Canada: Demographic, Economic, and Social Challenges. Toronto: University of Toronto Press.

Boyd, M. and M. Vickers. 2000. "100 years of immigration.” Canadian Social Trends Autumn, $58: 2-12$.

Boyd, M., J. DeVries, and K. Simkin. 1994. "Language, economic status and integration: Australia and Canada compared." Pp. 549-577 in Lois Foster, ed., Immigration and Refugee Policy: Australian and Canada Compared. Volume II. Melbourne, Australia: University of Melbourne Press.

Canada. 2008. "Regulations amending the immigration and refugee protection regulations (Canadian experience class)." The Gazette. 142(32): August 9, 2008. canadagazette. gc.ca/partI/2008/20080809/html/regle1-e.html. Accessed January 12, 2009.

— n.d. "Citizenship and immigration, 2007-2008." Estimates. Part III. Report on Plans and Priorities.

Carnevale, A.P., R.A. Fry, and B.L. Lowell. 2001. "Understanding, speaking, reading, writing, and earnings in the immigrant labor market." American Economic Review 91(2):159_ 163.

Centre for Canadian Benchmarks. (n.d. a) "What are the Canadian language benchmarks?" www.language.ca/display page.asp?page id=206. Accessed July 23, 2008. 
(n.d. b). "Frequently asked questions: What are the Canadian language benchmarks?" www.language.ca/display page.asp?page id=253. Accessed January 9, 2009.

Chiswick, B.R. and P.W. Miller. 2003. "The complementarity of language and other human capital: Immigrant earnings in Canada." Economics of Education Review 22(5):469-480. 2002. "Immigrant earnings: Language skills, linguistic concentrations and the business cycle." Journal of Population Economics 15(1):31-57.

_ 1995. "The endogeneity between language and earnings: International analyses." Journal of Labor Economics 13(2):246-288.

Citizenship and Immigration Canada. n.d. "Facts and figures 2007 - Immigration overview: Permanent and temporary residents." www.cic.gc.ca/english/resources/statistics/ facts2007/index.asp. Accessed December 20, 2008.

1998. "Medium term strategic research framework (June)." www.cic.gc.ca/english/ resources/research/framework.asp. Accessed July 29, 2008

2004. "Evaluation of the language instruction for newcomers to Canada (LINC) program." www.cic.gc.ca/ENGLISH/resources/evaluation/linc/exec-summary.asp Accessed July 23, 2008.

_ 2005a. "Backgrounder: Enhanced language training." www.hrsdc.gc.ca/en/cs/comm/ hrsd/news/2005/050425ba.shtml. Accessed July 23, 2008.

2005b. "Backgrounder: Higher level English as a second language training for the internationally trained." www.cic.gc.ca/english/department/media/backgrounders/2005/2005-01-20.asp. Accessed July 23, 2008.

- 2007a. Annual Report to Parliament 2007. www.cic.gc.ca/english/resources/publications/annual-report2007/introduction.asp. Accessed July 23, 2008.

2007b. "Backgrounder: Settlement funding allocations for 2008-09." www.cic.gc.ca/ english/department/media/backgrounders/2007/2007-12-17.asp. Accessed June 18, 2008.

Dustmann, C. and A. Van Soest. 2002. "Language and the earnings of immigrants." Industrial and Labor Relations Review 55(3):473-492.

Dustmann, C. and F. Fabbri. 2003. "Language proficiency and labour market performance of immigrants in the UK." Economic Journal 113:695-717.

Frenette, M. and R. Morissette. 2005. "Will they ever converge: Earnings of immigrant and Canadian-born workers for the last two decades." International Migration Review 39(1):229-258.

Galarneau, Diane and Rene Morissette. 2008. "Immigrants' education and required job skills." Perspectives on Labour and Income (December): 5-18. $\quad$ www.statcan.gc.ca/pub/75001-x/75-001-x2008112-eng.htm. Accessed December 22, 2008.

Grondin, C. 2007 Knowledge of Official Languages among New Immigrants: How Important is it in the Labour Market? 2005. Ottawa: Statistics Canada. Catalougue no. 89-624XIE.

Hodson, R. 1985. "Some considerations concerning the functional form of earnings." Social Science Research 14:374-394.

Kelley, N. and M. Trebilcock. 1998. The Making of the Mosaic: A History of Canadian Immigration Policy. Toronto: University of Toronto Press.

Keung, Nicholas. 2008. "New migrant class draws few: Program to retain skilled immigrants 
attracts just 210 applicants since its launch in September.” The Toronto Star. November 24. p. A13.

Knowles, Valerie. 2007. Strangers at our Gates: Canadian Immigration and Immigration Policy, 1540-2006, 3rd Edition. Toronto: Dundurn Press.

Koenker, R. and G. Bassett, Jr. 1978. "Regression quantiles.” Econometrica 46:33-50.

Koenker, R. and Z. Xiao. 2002. "Inference on the quantile regression process.” Econometrica 70:1583-1612.

Kossoudji, S.A. 1988. "English language ability and the labor market opportunities of Hispanic and East Asian men.” Journal of Labor Economics 6:205-228.

Manpower and Immigration, 1974. Immigration and Population Statistics. Ottawa: Information Canada.

McDonald, L., U. George, L. Cleghorn, and K. Karenova. 2008. An Analysis of Second Language Training Programs for Older Adults Across Canada. Toronto: University of Toronto, Institute for Life Course and Aging. www.settlementatwork.org/downloads/ Older Adults and Language Training Report 2008.pdf. Accessed July 25, 2008.

Park, J.H. 1999. "The earnings of immigrants in the United States: The effect of Englishspeaking ability." American Journal of Economics and Sociology 58(1):43-56.

Pendakur, K. and R. Pendakur. 2002. "Language as both human capital and ethnicity." International Migration Review 36(1):147-177.

Remennick, L. 2004. "Language acquisition, ethnicity and social integration among former Soviet immigrants of the 1990s in Israel." Ethnic and Racial Studies 27(3):431-454.

Shields, M.A. and S.W. Price. 2002. "The English language fluency and occupational success of ethnic minority immigrant men living in English and metropolitan areas." Journal of Population Economics 15:137-160.

Statistics Canada. 2005. "Longitudinal survey of immigrants." www.statcan.ca/Daily/English/051013/d051013b.htm. The Daily, October 13. Accessed July 18, 2008.

- 2007. "Longitudinal survey of immigrants." www.statcan.ca/Daily/English/070430/ d070430b.htm. The Daily, April 30. Accessed July 23, 2008. 
